\title{
A Sober Reflection on Present TESOL in China - From a TESOL Teacher's Perspective
}

\author{
Daohuan Duan ${ }^{1}$ \\ ${ }^{1}$ School of Foreign Languages, Sias International Institute of Zhengzhou University, Xinzheng, China. \\ Correspondence: Daohuan Duan, School of Foreign Languages, Sias International Institute of Zhengzhou \\ University, No.168, Renmin Road, Xinzheng 451150, Henan Province, China. E-mail: duandaohuan@163.com
}

Received: October 29, 2012 Accepted: January 1, 2013 Online Published: February 28, 2013

doi:10.5539/ass.v9n3p72 URL: http://dx.doi.org/10.5539/ass.v9n3p72

\begin{abstract}
First of all, this paper explores the existing problems in present CET (college English teaching) in China. The problems it focuses on are: lack of necessarily proper guidance on learning; lack of practically helpful teaching books; lack of correct teaching orientation and lack of efficiency. After analyzing the factors leading to the existing problems in CET, it concentrates on the resolutions to the issues. It goes like this: establishing the necessity of comprehending the nature of the English language; calls for another practical teaching innovation; de-administration in school-level institutions.
\end{abstract}

Keywords: college English teaching; orientation, problems, contributors

\section{Introduction}

English has been learned as a foreign language for decades in China. Chinese students are required to learn English as a compulsory course in $3^{\text {rd }}$ grade when they are in primary school. Since they have to learn English for at least twelve years in school if they don't want to pursue a higher degree, not to mention the after--school learning. Accordingly they are expected to be good at applying it. However, most students' English performance is far from 'good'. Hence complaints about English teaching, especially College English teaching have never stopped. This essay aims to explore some problems existing in college English teaching and to put forward some suggested solutions to the said problems.

The study of English in China has greatly changed Chinese people's concept of learning a foreign language, and it has also created a significant number of people who are good at using it. But what cannot be ignored is that it has also contributed to many problems as follows.

\section{Problems Existing in College English Teaching}

\subsection{Lack of Necessary Guidance on Learning}

As far as I am concerned, the biggest problem is the lack of proper guidance on how to learn. In China most attention is given on how to teach English rather than how to get students to learn the related knowledge, such as why and how they should learn English. The students come into the classroom waiting to be taught but not knowing how to learn. Most of the students clearly understand that they have to learn English, because English is required if they want to receive higher education. Furthermore, traditional research also focuses on theories regarding how to teach from the teachers' perspective, consciously or unconsciously ignoring learners' need, which partly explains why TESOL is less effective in China.

\subsection{Lack of Practically Helpful Teaching Books}

Currently, college English teaching books available in China are all designed by experts other than teachers, mostly linguists. Not only that, but learners are seldom invited to decide what they expect to be taught. Besides, those teaching books are relatively backward because it takes time to revise the imported English textbooks. A study of textbooks conducted by Min Cui (2010) from Jilin University, found that over $50 \%$ of the 1,036 sophomore students wanted to totally change the currently used textbooks, which were supposed to better satisfy students' real need.

\subsection{Lack of Correct Teaching Orientation}

Not only is exam-oriented English teaching common in high schools, but also in higher education institutions. 
College English Test (Band 4 and 6) for non-English major students are the motives of most students' learning purpose. Not only that, but it also plays a significant role in teachers' in-class teaching. Many universities and even the prospective employers put the mark of band 4 and 6 in the first place. What makes it worse is that students' performance in CET is used to estimate college English teachers' teaching. As a result of all of the above, College English Teaching (CET) has entered a vicious cycle in which the lack of student interest leads to a lack of positive motivation for teachers. According to the survey conducted by Dingfang, Shu (2010) in Jiangsu University, Yangzhou University and Zhejiang University of Science and Technology, among 1408 students, not a few of the participants express the idea that the exam-oriented CET (College English Teaching) cannot provide them with expected knowledge which they can use in daily life and future works, so they have no interest to learn it.

\subsection{Lack of Efficiency}

Compared with other basic learning, English learning takes the longest time in China, even in the whole world. Twenty years ago, Chinese students learned English starting in junior middle school. As time went on, the age became younger and younger, until presently, even some kindergartens teach English. If we take a kid learning English from $3^{\text {rd }}$ grade as an example, after he gets a Bachelor degree, he would have been learning English for at least 11 years, not to mention if he goes on in his studies for a Master degree or a PHD. But statistics show quite a few college students are not satisfied with the outcome. According to Jimei, Xia(2003), 55.86\% students who have passed the Band 4 or Band 6 CET (College English Test) said they didn't feel they improved much at the university level. This survey was done in some well-known Guangdong universities among 1,000 students. Hai Yu concluded that $20 \%$ of the 1,615 college students in Shanghai believed their English level is lower than it was when they were in high school. Jigang Cai (2010)surveyed students from 21 universities in China on the effectiveness of College English Learning, in which $44.4 \%$ of students answered that they made no progress on English learning, and their level is even lower than what it was in high school. So lack of efficiency has not only made students and teachers unsatisfied, it has also caused parents to worry. They say they have paid much more money for their children on English learning, but they are not satisfied with the outcome.

\section{Factors Contributing to the Existing Problems}

Listing the problems could go on and on, but what is better is to find reasons for the existing problems. According to me, the following factors have and continue to be contributing to the problems.

In the first place, most students don't know why they are learning English. They just know they have to. This is mainly due to the absence of in-time guidance from related English teachers, who also need to make sure of it. Then why do we need to learn English? Are we learning it for all different kinds of examinations? A majority of teachers agree with the idea that language is the tool for communication. Although this is true, to me Language is not only a tool of communication, but also the means for enriching our lives and gaining insights into other cultures, in order to bridge cultural gaps. Examinations should only be used to motivate our study and measure our knowledge, rather than be the goal. The ultimate purpose of learning should be to use it.

Secondly, with more and more students being admitted into universities, English teachers are in great demand, especially excellent English teachers, which are always in short supply. This is another ongoing problem needing attention. Most English teachers are overloaded with their teaching assignment, with no time or energy to do research and learn, working like machines. Without competent and energetic teachers, how is it possible to cultivate better students? If this won't be paid enough attention, things will go on like this, and probably nothing could be improved in TESOL in China. So the present situation calls for competent teachers who are eager to have more time to do related research.

Thirdly, misleading guidance on English learning plays a worse and worse role. Examinations are put before practical skills. Although comprehensive ability is what is expected, research indicates that most organizations and employers are not satisfied with recent graduates' English competence, which suggests only a few of them are competent for international conferences or negotiations. To a great degree this is due to the over-emphasis on a variety of examinations, such as CET (College English Test, band 4 or 6), TEFOL, GRE, SAT, and other entrance examinations. We cannot deny the positive role these examinations have played, but what is more important is the negative influence they have had. All of those exams have gotten learners stuck in a dilemma which they are already aware of but cannot get rid of.

\section{Resolutions to the Existing Problems}

Problems existing in College English Teaching have been passionately discussed; CET has undergone several innovations, while it still goes on as it went on decades ago. Now a need for other innovation is on the increase. 
It seems that the more changes it has had in the past, the more confusion will be present about how to alter it. Anyhow, it is critical that actions should be taken to abandon this urgently-waiting-to-be-resolved burden. Then how to get rid of this burden is the question. I strongly recommend the following:

First of all, we need to figure out what is the nature of English language. We have to admit that actually language is a tool, but it is a different one. (Han, 2010) Mastery of this language can not only make us reach out to native English speakers, it can also better ourselves, which is expected to be a key factor in cultivating a fullydeveloped person. Thus English enables us to become wiser and smarter, even more elegant. This is often called cultural quality. And this should be the top priority when goals of learning English are being drafted. Student should be informed of this nature of language instead of the usefulness in passing different examinations. Still, as is known to all, English is a global language. It plays a crucial role in the internationalization of higher education, which mainly includes internationalization of teachers, students and courses. English is the most important teaching foreign language committed in China. Without it, internationalization of higher education would be a myth.

Secondly, another circle of teaching method innovation is in urgent need. English is being taught in grammar-translation method in which grammar is taught as knowledge for nearly half a century in China. I am not implying that this long-lasted method is not good. Practically there is much to be gained from this method. And we have witnessed it played and continue to play an irreplaceable role in present college English teaching. Ellis has explained the importance of grammar teaching from three aspects, in which she amply interpreted the necessity and significance of grammar teaching. (Ellis, 2002) To me, English is like a pearl necklace, and grammar is the string which holds pearls (including words and fixed phrases) together. The importance of grammar is obvious here, and I have to admit that grammar serves for communication. But now the fact is that grammar-translation teaching is partly and slowly being replaced by some skill-training methods in which skill-training is put in the first place. Among them communicative teaching is particularly advocated by linguistic experts and is being widely employed in high schools in China. And that is what I am concerned about. I think the overemphasis of communicative method leads to a poor grasp of grammar in college students. And it has made college English teachers very upset. Should we overemphasize one teaching method and ignore another one? No, never. According to Kumaravadivelu (Kumaravadivelu, 1994), there is not a so-called best method in foreign language teaching. Thus different approaches are critical and should coexist rather than one being taught at the expense of the other.

Thirdly, de-administration is necessary not only on a national level, but also at the institutional level, including schools at all levels. Administration has made teachers grow tired of teaching because they have no say in school-level policy-making. Language is a science around us, so an administrator is more likely to believe that his personal learning experience is the universal law of language learning. Hence probably he will apply his experience-based theory to instruct the concrete teaching, (Gui, 2010) which unavoidably push teachers into a dilemma they want to get away from but are stuck with. Actually it is the English teacher who is best qualified to create teaching policy. If another round of innovation is on the schedule, ordinary teachers should be invited to discuss the specific content of textbooks because they know what is exactly needed by the students. What should be remembered is that when textbooks are going to be compiled, students should also be invited to participate in the compiling of their own learning materials. In fact it's the students themselves who know precisely what can arouse their curiosity and interest, and that is what has been neglected as if they do not exist.

Last but not least, if we could accomplish the above, the concept of examination-orientated teaching will be naturally weakened. But it remains to be seen whether we can achieve that dreamed goal.

\section{References}

Baocheng, H. (2010). Reflections on English Education at Schools in China. Foreign Language Teaching and Research, 42(4), 300.

Ellis, R. (2002). The Place of Grammar Instruction in Second/Foreign Language Curriculum. In E. Hinkel, \& S. Fotos (Eds.), New Perspectives on Grammar Teaching in Second Language Classroom (pp. 17-34). Mahwah, N.J. Lawrence: Lawrence Erlbaum.

Jigang, C. (2010). Reflections on the Orientation of English Language Teaching in Chinese Higher Education. Foreign Language Teaching and Research, 42(4), 306.

Jigang, C. (2011). Research on the Differences of English Teaching Pattern between Ningbo Norttingham Universty and Fudan University. University Teaching in China, 1.

Jimei, X. (2003). Discussion on the College English Teaching Reform: Regarding the Substantive Promotion of 
College English Teaching Reform. University Teaching in China, 30-33. Retrieved from http://wuxizazhi.cnki.net/CNKIVI

Kumaravadivelu, B. (1994). The Post method Condition: Emerging Strategies for Second Foreign Language Teaching. TESOL, 28, 27-48. http://dx.doi.org/10.2307/3587197

Min, C. (2012). New Evaluation System Research and Practice on University English Teaching Model. Foreign Language in China, 2.

Shichun, G. (2010). Reflections on Some Issues in Foreign Language Teaching in China. Foreign Language Teaching and Research, 42(4), 275. 